\title{
Perceptions of ICT Careers in German Schools: An Exploratory Study
}

\author{
Liisa von Hellens, Kaylene Clayton, \\ Jenine Beekhuyzen, and Sue Nielsen, \\ Griffith University, Brisbane, QId, Australia
}

\author{
L.vonHellens@griffith.edu.au; K.Clayton@griffith.edu.au; \\ J.Beekhuyzen@griffith.edu.au; S.Nielsen@griffith.edu.au
}

\begin{abstract}
This paper reports on an exploratory investigation of the perceptions of information and communication technology (ICT) as a field of study and work in German secondary schools. A total of 160 students from five secondary schools in Lower Saxony participated in the study in February 2007, and four teachers of the students were interviewed. The investigation is part of the research carried out by the authors within the Griffith University Women in Information Technology (WinIT) project, which has been studying the problem of low female participation since 1995. In this paper we discuss German school students' (male and female) and their teachers' views of ICT, its use at school and home, their influences in using technology, and their ideas about working with technology in the future. We drew on the challenges faced and opportunities available to teachers in the study to put this in context. We found that many senior secondary students have not decided what they want to do when they finish school, suggesting that the environment is ripe for them to receive relevant and useful information that may help them to choose to study tertiary ICT courses. By dispelling negative ICT perceptions and allowing students to make an informed choice as to whether to take up a career in ICT, we can hopefully encourage more students into this ever-growing and exciting industry.
\end{abstract}

Keywords: Information and communication technology (ICT) education, perceptions of ICT careers, secondary school students, secondary school teachers, gender in ICT education, crosscultural comparison, German schools, Australian schools.

\section{Introduction}

This paper presents the results of an investigation of secondary student's and their teachers' perceptions of information and communication technology (ICT) education and work. The study is exploratory in nature, and the paper discusses the context - German secondary schools - and the conduct of the study that took place in Lower Saxony, Germany in February 2007. Given the con-

Material published as part of this publication, either on-line or in print, is copyrighted by the Informing Science Institute.

Permission to make digital or paper copy of part or all of these works for personal or classroom use is granted without fee provided that the copies are not made or distributed for profit or commercial advantage AND that copies 1) bear this notice in full and 2) give the full citation on the first page. It is permissible to abstract these works so long as credit is given. To copy in all other cases or to republish or to post on a server or to redistribute to lists requires specific permission and payment of a fee. Contact 0HPublisher@InformingScience.org to request redistribution permission. tinuing downturn of ICT enrollments in western democracies this study is significant as it provides advice on strategies to increase school students' interest in ICT studies. This paper complements our previous studies in Australia and similar studies in Germany and in other countries.

Drawing on the challenges faced and the opportunities available to the teachers in 
the study also helps to put the findings in context and provide advice on strategies to increase the students' interest in ICT studies and careers.

Secondly, our objective is to collect comparative information about students' perceptions of and abilities in ICT studies in Germany for the Women in Information Technology (WinIT) project. The WinIT project has, since 1995, explored the cultural and contextual factors that influence female high school and tertiary students in decisions to undertake ICT and remain in ICT education and work (see http://www.winitproject.com). The opportunity to carry out research in Hanover, Germany came when the authors of this paper, the WinIT project researchers, were invited to develop and deliver an undergraduate lecture series on gender and ICT for computer science and business students at the University of Applied Science and Arts (Fachhochschule Hanover) in February 2007.

A guest professorship at the University of Applied Science and Arts funded by the Maria Goeppert-Mayer Programme for International Gender Research enabled the authors to develop the study and gain access to schools around the Hanover area in Germany. We conducted the school research for this paper alongside delivering an undergraduate university course aimed at increasing the awareness of the gender imbalance in information and communication technology education and work. Our experience of developing and delivering the novel undergraduate course in gender and ICT is beyond the scope of this paper but documented in the authors' other publication (von Hellens, Nielsen, Clayton, \& Beekhuyzen, 2007). However the discussion presented in this paper contributes to research on interventions aimed at increasing female participation in the ICT field, while informing actions related to interventions for females in ICT.

Research shows that German ICT programs not only lack female students but also do not appeal to young people of either sex (Munder, 2005). Labor statistics from other countries also confirm the continuing gender imbalance in ICT education as well as in work (Craig, 2008). Studies show obstacles for women in the ICT industry; despite delaying having a family, women still miss top jobs and tend to leave the industry to pursue other careers (Simard, Davies Henderson, Gilmartin, Schiebinger, \& Whitey, 2008).

CIO Insight cites research by the Bureau of Labor Statistics in the USA that shows that employment of women in a broad range of ICT positions has declined in relative and absolute terms over the past several years (Cone, 2007). According to Cone (2007) some 984,000 women worked in eight IT categories in 2000, accounting for 28.9 percent of all employed IT workers. The corresponding numbers for 2006, when overall IT employment hit an all-time high of nearly 3.47 million, show a 7.7 percent drop from 2000, with 908,000 women working in IT, or just 26.2 percent of the total (Cone, 2007). In our previous work we have explored the many strategies that are in place in Australia to reverse the trend of lack of female participation in this important area, and we have acknowledged that to date there has been little concrete evidence of their success.

The recent research report on equal opportunities and interest in undertaking a career in German science and technology professions points out several issues contributing to the gender imbalance in these areas (Haffner, Könekamp, \& Krais, 2006). The research by Haffner and colleagues (2006) was sponsored by Federal Ministry of Education and Research in Germany. The main finding states that unless there is a change in the workplace culture to actively contribute to a good work life balance and help women integrate into the working environment, the gender imbalance will continue. Despite the fact that females overall are doing academically better than the male students in secondary schools, they are not taking up ICT. It is in this context we discuss the student and teachers findings of our exploratory research in Germany.

It is suggested that the unbalanced and unfair ICT work situation referred to above has implications for young females' interest (or lack of interest) in ICT programs. The problem of declining female participation in ICT education and work is two fold. Firstly, women are not encouraged to study information technology for a variety of reasons; and secondly, the information technology profession is not well understood (perceptions of working long hours, sitting alone in front of a 
von Hellens, Clayton, Beekhuyzen, \& Nielsen

computer with little social interaction) and thus is generally regarded as boring by young people, male and female. These two aspects are related but in this paper we focus on the latter, i.e., the perceptions young people have about ICT as a field of study and work. To do this we discuss the survey results from students and the findings from our teacher interviews.

\section{Background Literature}

Information Technology (IT) or Information and Communication Technology (ICT - as it is often referred to) education and work was originally thought of as a 'level playing field' where gender would be irrelevant, allowing flexibility in time and space. However this has not been translated to student numbers in ICT university courses. For example, female students in Australian high schools today lack interest in going on to study toward ICT degrees in universities, and the number of female ICT graduates continues to be low, less than twenty percent of all university ICT degree programs. This decline is even more surprising considering the rise in female participation in the traditionally male-dominated professions of engineering, law, medicine, and science (von Hellens \& Nielsen, 2001).

In addition to gender differences, von Hellens and Nielsen (2001) also found that women of Asian background significantly outnumber all other ethnic female students in Australian ICT degree studies, suggesting cultural differences may be more important than gender alone. WinIT research among high school students has showed that females of Asian background were more willing to consider ICT university courses than their the non-Asian counterparts suggesting cultural differences even at the high school level (Greenhill, von Hellens, Nielsen, \& Pringle, 1997). The same research also suggests no cultural differences in terms of regarding the ICT field as 'boring'.

With the overall increase of female participation in the workplace and the requirement in most countries to eliminate discrimination, harassment, and other unfair work practices, the issue of gender remains a problem for ICT education and work.

Information and Communication Technologies are an accepted part of everyday life. Most current school children do not know a life without ICT as they have been integrated into all aspects of their life including home (e.g., watching a DVD), school (e.g., playing educational computer games), and personal life (e.g., talking to friends on a mobile phone). However, the vast acceptance and integration of ICT into society has generally not translated into a desire to create new technologies and to be involved in the ICT industry. Research has shown that the number of students choosing to undertake specialised studies in ICT is not growing at the same rate as with other degree or study programs (Beekhuyzen, Nielsen, \& von Hellens, 2003).

There are many factors that contribute to this declining interest in information and communication technology (ICT) educational and vocational pathways including cultural, social, structural, and individual factors (Adya \& Kaiser, 2006). Adya and Kaiser's original model (2006) has been extended in the recent doctoral dissertation by Clayton (2007), this paper's second author. The study's extensive empirical research provides rich insights and new concepts on young women's ICT career decisions and helps us in analysing and discussing the German student and teacher findings.

Cultural influences shape perceptions about ICTs and how they are used (Harris \& Wilkinson, 2004). For instance, ICT is commonly stereotyped as a masculine domain and society has perpetuated the myth that subjects such as mathematics, science, and computing are inappropriate for girls, even when they have shown exceptional aptitude for these subjects (Camp, 1997). According to Camp (1997) these beliefs can be shared and spread amongst family, friends, and teachers.

Considerable evidence also points to the content and delivery of the secondary ICT curriculum being an important negative influence on students' interest in ICT careers (Newmarch, Taylor- 
Steele, \& Cumpston, 2000). Students frequently complain that ICT subjects are boring, and Newmarch et al. (2000) believe that this could be due to the focus on mastering software packages and the perception that ICT is simply word processing. Students are also being taught by teachers possessing a disparate range of ICT skills, partially due to the level of exposure the teachers receive in their pre-service education and professional development, along with their access to technology (Goldman, 2003). In addition, the lack of or poor quality ICT information at school can lead to poor perceptions of ICT and consequently low ICT enrolments, and teachers need assistance to help them remain current in curriculum, industry, and ICT career information (Clayton, 2004). Despite the ICT industry's cries for more applicants to fill vacant positions, research shows that gender stereotypes prevail and continue influencing girls' choices over time, reducing their confidence and interest in ICT and turning them away from ICT as an occupation (Clayton, 2007; Clayton, von Hellens, \& Nielsen 2009).

A number of intervention programs have been developed at all levels including schools, universities, and industry, to increase the number of females in ICT, but there is no systematic, measured evidence of the success of these programs (Craig, 2008). Lack of resources is suggested to be the reason as well as the low priority of such evaluations. These programs address the documented reasons of females' lack of interest in ICT careers and attempt to raise the general awareness of ICT study and career opportunities. One well-documented challenge to the awareness of ICT careers is the lack of female role models, and this has been addressed in a variety of ways. A recent example of an innovation in this area is the book Tech girls are chic, not just geek that is being distributed free to school students in Australia by Jenine Beekhuyzen, the third author of this paper (see www.techgirlsarechic.org). The message of the fun book is that females can have technology skills and be intelligent and sophisticated, fun and funky, and that being in computing is not boring.

Von Hellens and Nielsen (2001) studied high school students and found that all female students have similar views about the work of IT professionals, whom they generally characterize as people working alone with computers and having little contact with other people. They generally perceive computing as boring and difficult and IT study and work as strongly associated with logic or math skills, rather than literacy or interpersonal skills. Boys and girls alike generally view women as preferring work that requires personal contact and communication. They expect boys to be more interested in computers than girls, as computing continues to be considered a male pastime. However, they also believe that women's participation in IT will gradually increase, possibly because of the characters they've seen in films and other media. There was no indication they were aware that female participation started to clearly decline in the mid 1980s and that it has actually continued to decline ever since.

Individual factors, such as personality traits and intellectual qualities, are also an important factor to be considered (Trauth, 2002). These individual factors and the way that the student interprets the cultural, social, and structural factors are important in determining whether the student chooses to become involved in ICT educational and vocational paths. The problem of declining interest in the ICT field is a complex issue and cannot be attributed to any of these factors in isolation. It is the understanding of the relationships and interaction of all these factors that holds the key to addressing the declining interest in ICT education and work.

\section{Research Method}

\section{Purposive Sampling}

In order to carry out our exploratory research in secondary schools in Germany we first needed to identify the schools willing to participate in this research. Secondly, once the schools' agreement had been obtained, the permission from the Department of Education in Lower Saxony was re- 
von Hellens, Clayton, Beekhuyzen, \& Nielsen

quired. The relevant officers in the department (Landeschulebehörde) had to be contacted and the research details explained including the human research ethical clearance before they would provide a permission to carry out the research. Being non-German speakers, doing this from Australia would not have been feasible if we had not been already working with local professors at the University of Applied Science and Arts for the university level Gender and ICT course within the Maria Goeppert-Mayer Programme. The professors at this German university helped us with identifying possible schools and with explaining the research details to the key officers in the education department for permission to carry out the research. Our German colleagues (collaborators) contacted the schools by using their existing contacts with the ICT teachers in the local schools. This method of sampling is best described as purposive sampling. As pointed out in Maxwell (2005, p. 88), this is a strategy in which "particular settings, persons, or activities are selected deliberately in order to provide information that can't be gotten as well from other choices." Our German colleagues also prepared the German language summary documentation to the Education Department and we provided the supporting documentation, the English language details of the study, the questionnaires, and appropriate consent forms.

\section{Survey Questionnaire and Interview Agenda}

The survey questionnaire for the students and the agenda for the teacher interviews were adjusted from the previous WinIT project research and from the recent doctoral dissertation (Clayton, 2007) to suit this study. Our collaborators also accompanied us to the schools and helped us with the translation in describing our research to the students, explaining any unclear English language words to the student audience (such as using the world 'geek' - they were more familiar with the term 'nerd'), and assisted us in the teacher interviews.

In every instance, the survey team and interview team consisted of two authors and a German colleague. Although not the same two authors attended every school, as we had to work it alongside our teaching commitments, one author did attend every school enabling consistency in the introduction of the research and data collection. The rest of the interview team provided an 'extra set of hands' to help in answering questions, handing out Australian chocolates and koala toys for completed surveys and generally providing support in this unfamiliar environment. Details of the five schools included in the study are in the following section.

The quality of English language spoken by the students was generally good, enabling the research team to speak to the class as a whole and inform them of our purpose. This was very useful enabling the researchers to answer questions in English, as the research team members are not fluent in German language. The survey used to gather the data can be found in Appendix A.

\section{Conduct of the Study}

\section{Location}

As mentioned above a guest professorship enabled this study to take place in Lower Saxony (Niedersachsen) in Northern Germany. The following map (See Figure 1) shows the locations of the schools participating in the study. In referring to Table 1 below, Schools A, B, and C are located in the general Hanover city area (1), with School D located approximately 50 kilometres south of Hanover (2), and School E approximately 200 kilometres north-west of Hanover (3). All schools were co-educational. Apart from a few religious schools there are no single sex schools in Germany. Interestingly, however, in this part of Germany there are four university level women only computer science programs, for example the Internationaler Frauen-Studiengang Informatik B.Sc. in the University of Applied Science in Bremen (http://www.hsbremen.de/internet/de/studium/stg/ifi/). These programs are unique in the world evidencing the serious attempt to address the lack of female in the important ICT field in Germany. 


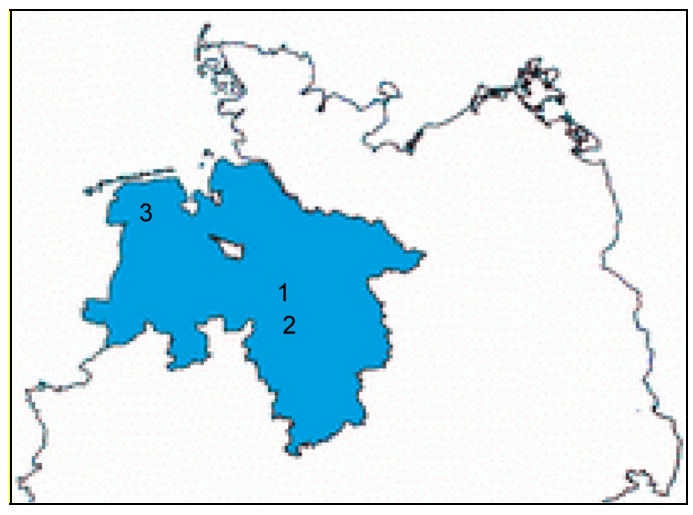

Figure 1: Map of Participating Schools

Table 1 provides details of the schools and students involved:

Table 1: Breakdown of Participating Schools

\begin{tabular}{|c|c|c|c|c|c|}
\hline School & Date & $\begin{array}{c}\text { \# of } \\
\text { partici- } \\
\text { pants }\end{array}$ & Participants & $\begin{array}{l}\text { School of- } \\
\text { fers a com- } \\
\text { puter course }\end{array}$ & $\begin{array}{l}\text { Teachers in- } \\
\text { terviewed }\end{array}$ \\
\hline $\begin{array}{c}\text { (A - 1) Gymnasium } \\
\text { Lehrte, Lehrte }\end{array}$ & $31 / 1 / 07$ & 20 & 20 girls & Yes & 1 Female \\
\hline $\begin{array}{l}\text { (B - 1) Gymnasium } \\
\text { Neustadt, Neustadt }\end{array}$ & $6 / 2 / 07$ & 50 & $\begin{array}{l}24 \operatorname{girls} / 25 \\
\text { boys, } 1 \text { not } \\
\text { stated }\end{array}$ & Yes & \\
\hline $\begin{array}{c}(\mathrm{C}-1) \text { Wilhelm- } \\
\text { Raade-Schule, } \\
\text { Hanover }\end{array}$ & $8 / 2 / 07$ & 9 & 5 girls/4 boys & Yes & \\
\hline $\begin{array}{c}\text { (D - 2) Sophien- } \\
\text { schule Hanover, } \\
\text { Hanover }\end{array}$ & $12 / 2 / 07$ & 40 & $\begin{array}{c}18 \text { girls/22 } \\
\text { boys }\end{array}$ & Yes & \\
\hline $\begin{array}{l}\text { (E - 3) IGS-Aurich- } \\
\text { West, Aurich }\end{array}$ & $13 / 2 / 07$ & 41 & $\begin{array}{c}24 \operatorname{girls} / 17 \\
\text { boys }\end{array}$ & No & $\begin{array}{l}3 \text { females, } 1 \\
\text { male }\end{array}$ \\
\hline Total & & 160 & $\begin{array}{l}91 \text { girls } / 68 \\
\text { boys, } 1 \text { not } \\
\text { stated }\end{array}$ & & \\
\hline
\end{tabular}

A total of 160 students voluntarily participated in the study as part of their daily classroom activities. Overall, 91 girls were represented in the survey from the 5 schools and 68 boys. One student didn't indicate his/her gender. It is important to note that one of the schools did not offer any computing subjects. Four teachers from two of the schools were interviewed: 3 female and one male.

\section{Data Collection}

The survey questionnaire presented to individual school students contained questions asking about their basic use of computers and if they are planning to undertake courses in computers and information technology (IT) at a tertiary level (i.e. university). The hard copy survey was completed in regular class time by students and returned within 20 minutes. All surveys were con- 
von Hellens, Clayton, Beekhuyzen, \& Nielsen

ducted in English, and we observed that the participating students generally had good English language skills.

As mentioned above, the questions asked in the survey were derived based on the authors' previous research in this area. They included information about personal background, computer use at school, perceptions about working with computers, and personal factors in studying (or not) computing. These questions give us insight into each individual student, while combined they give us a view of that particular school, which we can then put in context of location, demographics, and access to computers at the school. The data gives us a general view of the students and their computer use. A total of 160 students participated in the survey and their responses are summarised in Appendix B.

We found the surveys were a good way to get general background and basic activity information from the students. We feel that although we have an adequate number of usable responses, correlations will not add a lot of value to the discussion, as we need to know more about the students. In saying this, the unit of analysis for the study is students (who were unable to be interviewed). In keeping with our tradition of using the life history approach to gender issues in ICT, we also interviewed ICT teachers in the schools where we surveyed the students. This interview data allows us to put the student responses in context. Additionally, our observations and discussions with our local colleagues (from the university where we were working) over the two-week period also helped to inform our findings.

\section{Discussion - Students}

In this section we discuss the students' responses summarised in the Appendix B. Despite the apparent high level of computer knowledge and use, an ICT career was not regarded as a preferred career choice. Many of the students had not decided what they wanted to do when they finish school while in their senior years. Since the students had not decided what to do after they finish the school the environment may be ripe to distribute relevant and useful information that may help them to choose to study tertiary ICT. By dispelling some of these perceptions and allowing students to make an informed choice as to whether to take up a career in ICT, we can hopefully encourage more students into this ever-growing industry.

\section{High Levels of Computer Use Despite Regarding the ICT Courses as Boring}

The students had easy access to computers, with home being their primary place of computer access $(97 \%, 155$ students). Students were also active computers users; more than half of them are spending more than 10 hours using computers each week and also doing a computer subject at school.

A third of the students chose not do a computer course; the reason being such a course would be "boring." The perception that computing is boring was shared by a third of all students, not only the students who chose not to do computing. Only $12 \%$ of students wanted to learn more about computers and thus chose a computer course. The vast majority of students $(72.5 \%)$ liked problem solving and using computers, and many students (46\%) found computer courses to be interesting sometimes.

\section{Unclear Perception of Computing Courses and Profession}

Many students (35\%) found the courses to be different from what they expected, whereas $29 \%$ thought the courses to be as they expected them to be and the remainder made no comment on this aspect. The students' answers demonstrated lack of understanding of the non-technical na- 
ture of the computing profession. The tasks suggested for a person with computer training were predominantly technical and closely related to software and hardware, whereas people oriented tasks, such as sales, supervising, training, and clerical, were not regarded to be occupations that people with ICT education and training participate in.

When asked what traits a person who works with computers has, overwhelmingly the combination of responses were that such a person is smart, a problem solver, and creative. These were the first three options listed for this question; however, they were able to choose more than one answer. Overall, 'creative' was indicated 91 times, 'a problem solver' 88 times, and 'smart' 63 times. The other options: quiet, a nerd/geek, hardworking, unhealthy, shy, which are generally associated (wrongly) with a computer professional, were not selected as often.

An important aspect of the computing profession such as being a team player was mentioned (21 times). Being rich was mentioned by only ten students, suggesting that the students were not aware of the relatively high wages of computing professionals.

\section{Gender and Equity Issues}

Almost half of the students suggested that they felt boys are better were with computers than girls and the remaining students said the opposite. This may be related to the gender balance of the survey audience (females $58 \%$ and $42 \%$ males) rather than a considered opinion.

Students were also not worried about being seen as possessing computer knowledge; the vast majority $(87 \%)$ of students didn't believe others would make fun of them if they were able to answer computer questions in class. They did also did not think that being good at mathematics is a requirement for being good in the computing field.

\section{Lack of Specific ICT Career Plans}

The students predominantly did not know what they would to do after finishing school, but only a fraction (13\%) would consider studying computers at technical college or university. Only 14\% of the students were not discouraged from studying computing, which we think reflects the widely documented general public's inaccurate opinion that computing is boring and suitable for loners and that there is a lack of jobs in computing. Some students reported that their mothers, family members, and friends had discouraged them from being involved in computing.

This research indicates that parents and friends are the most influential people in children's career decisions (see for example Clayton, 2007) and some students were encouraged to study computing by more than one person. This person was a family member, friend, or teacher. However, our study demonstrated that the students lack specific ICT career plans.

\section{Desire to Work with People}

Working with other people and challenging and interesting work were important to the students when choosing a career. Given twelve options to answer, working with other people, interesting work and challenging work were the three most recorded answers. This was interesting because the options were listed in the following order one below another: working with other people, high salary/wages, interesting work, and challenging work (and others), and while the three options listed above were chosen, the option of high salary/wages was often skipped over and not selected at all. 
von Hellens, Clayton, Beekhuyzen, \& Nielsen

\section{So What?}

To gain an understanding of the perceptions young people have about ICT education and work, it is useful to reflect on the discussion so far.

There are some similarities between Australia and Germany in terms of why students enrolled in ICT subjects. At some German schools, students chose the Computer Science (CS) subject because they did not like the physics teacher or biology and they had to choose between physics, $\mathrm{CS}$, and biology. In these CS classes, the female to male ratio was much higher than in CS classes where the students purposefully and willingly chose the CS subject. When the students chose the subject out of interest and personal motivation, girls made up approximately $20 \%$ or less of the class. Unlike Germany, many Australian senior school ICT subjects count towards university entrance scores. Moreover, while some Australian students choose ICT subjects due to personal interest, others choose it because of timetable restrictions or as the easiest or most appealing choice of unfavoured options.

In Germany, the students use computers primarily at home, with school being another place that they use computers regularly. Whether it is at home or at school, every student in the study said that they used a computer for at least one hour per week. Almost half of the students surveyed studied a computer subject at school, however, one of the five schools in this study did not offer a computer subject at school (this affected 41 students out of 160 in our study). The main reason given for not studying a computer subject was that it is boring. Most students found the computer subjects they study sometimes interesting and many found that studying computing was not what they thought it would be like.

The majority of German students indicated that they enjoy solving problems and doing things with a computer. Overwhelmingly they believe that programming is the type of work that a person with computer training does. Furthermore, the majority of students do not believe that mathematics aptitude is necessary to be good with computers. The views were pretty evenly split when asking students if boys are better with computers than girls. Interestingly $67 \%$ of the girls that responded (yes/no) don't believe boys are better while $71 \%$ of the boys that responded (yes/no) believed boys were better with computers than girls.

Working with other people, interesting work, and challenging work were the three most important aspects considered by the German students when choosing a career. Being smart, a problem solver, and creative are the three most common traits that they believed that a person working with computers would have. Just more than half of the students said that they knew what they want to do when they finish school, and most had not considered studying computers in tertiary education. Some students had been discouraged from studying computing, but a number also reported that they had been encouraged to study computing.

\section{Discussion - Teachers}

Teachers who worked at two of the five schools were interviewed on the same day that the students were surveyed. To give insight into the teacher interviews, we put them into the context of previous findings from the WinIT project (www.winitproject.com) and from this paper's second author's PhD dissertation (Clayton, 2007).

Similar to the Australian situation, the German teachers see no difference in the level of ICT ability of boys and girls, but there are differences in how they believe the students use and feel about computers. Boys' computer use is seen to be more exploratory, and they are believed to be less concerned about the outcome of their action. Girls' computer use is felt to be more restrained, systematic, and cautious. Furthermore, the German teachers feel that girls want their work to "look good," while the boys were more interested in how technology works. 
We found agreement amongst the teachers interviewed that it is difficult to motivate the German students and that the Internet, the availability of software, and computer games may influence this. Many students use the Internet as a mode of communication enabling them to see the social side of ICT. A similar situation occurs in Australia.

Some teachers in Germany also commented that the students are not interested in creating computer software because they have no need; the software that they require is already available and they see computers as a black box. Another teacher also believed that computer games have influenced the way that students enjoy new technologies, as they lack patience and quickly become bored and disinterested. This is also in line with findings from Australia.

There are also many similarities in the concerns of the German teachers to the ICT teachers in Australia (see Clayton, 2004, 2007). As with the Australian teachers, the German teachers commonly express concerns about inadequate ICT resources and support at the schools. They frequently refer to the cost of software and hardware and feel that the worst thing about teaching with technology was problems with the reliability of the ICT resources. Many of the German teachers are also maintaining their school's computer network and ICT resources. However, the teachers at some of the German schools have the assistance of teams of schoolboys to help maintain the school network and resources; at one school, these students received payment for their work. In comparison with Australia, depending on the socio-economic status of the school, Australian ICT teachers are often required to assist with network administration and technical support, especially if the problem is urgent. This is done on top of their normal teaching load. However, it is more unusual in Australia for students to be paid as an assistant technician or even assist the teachers.

Similarly to Australian teachers, German teachers spoke about their lack of time to prepare curriculum items for their ICT classes and remain current with new technologies and skills. In Germany teachers are assigned to teach two subjects as their normal workload; ICT subjects are not normally considered as one of those subjects. This means that German ICT teachers have a subject load of three subjects and are often assisting with the maintenance of the computers and networks at the schools, as well as attempting to update their skills. Some of the German teachers had access to professional development through their schools, while other teachers were left to find their own way. Australian teachers have more access to structured professional development through their school or the Education Department. However, communication of training opportunities and the temporal and financial cost of the training to the teacher often hindered their efforts.

In Germany, there are few new Computer Science teachers being trained and it is uncommon for teachers to swap schools, except for career reasons. Furthermore, of the German teachers interviewed, approximately half of the ICT teachers had worked in the ICT industry prior to their teaching career. This is a very different situation to Australian public schools, where teachers are assigned to a school by the Education Department and may be required to or choose to change schools a number of times during their teaching career. This can be for operational and personal reasons, such as increases and decreases in student population and when the teachers move between suburbs, towns, cities, or even states. It is far more uncommon for Australian ICT teachers to have an ICT industry background; many of the teachers have a business studies, science, or mathematics teaching qualifications and have entered the role of an ICT teacher out of school need or personal interest in ICT. It is significant that in both Germany and Australia that the teachers who were enthusiastic about ICT had more enthusiastic students.

Lastly, but important to note, German teachers believe that the ICT job market has not recovered since the dot com crash, which is similar to the beliefs of Australian teachers. However the ICT job market is on the increase rather than in decline, especially in Australia as the industry is beginning to feel the impact of reduced ICT enrolments and interest in the ICT field. 
von Hellens, Clayton, Beekhuyzen, \& Nielsen

\section{Conclusion and Recommendations}

The paper presents the results of an investigation of secondary school student's perceptions of ICT education and work. We outlined German school student's views on ICT, how they use it at school and home, their influences in using ICT, and their ideas about working with ICT as part of their future. We drew on the challenges faced and opportunities available to teachers of the students in the study to put this in context.

Existing research (for example, Clayton, 2007) shows that two of the most common reasons for the lack of females (and students in general) entering tertiary ICT study is the lack of role models and the lack of understanding of what an ICT career is. Our study confirms previous findings; the situation in the selected German schools is similar to other western economies.

Students are using computers regularly so they are not unfamiliar with them, which can be a great start to enter ICT pathways at a tertiary level. They also appear to like using computers, as many of them spend many hours a week on them. We need to tailor school curriculum to be more 'interesting' and let students in younger years know what ICT courses and careers really are about. It is necessary to change the perceptions about studying and working in ICT and show that solving problems is a core part of it. The students in our study realise that mathematics is an important, but not essential, part of an ICT or computing career. However, the students do not recognise the connection between what the students generally wanted from a career and the opportunities that a computing career could offer.

This study confirms the need to change the perception that ICT is not just about programming. The students' perceptions of ICT or computing careers should be that it is creative and encompasses many technical and non-technical roles. The student perceptions recorded in this study fit with previous research. Common challenges faced by German teachers are a lack of resources and training which is also consistent with the challenges reported in other studies.

In their senior education years, because many students haven't decided what they want to do when they finish school, the environment is ripe for them to receive relevant and useful information that may help them to choose to study tertiary ICT subjects. By dispelling some of these negative perceptions and allowing students to make an informed choice to engage in an ICT career, we can hopefully encourage more students into this ever-growing and exciting industry.

\section{Acknowledgement}

The researchers would like to thank the participating schools (students and teachers) for their involvement, as without their cooperation this research would not have been possible. The authors would also like to thank our German colleagues Georg Disterer and Elisabeth Dennert-Möller. We also thank the Maria Goeppert-Mayer Programme for International Gender Research for funding and for enabling the WinIT team to carry out this research in German schools. This research has obtained the Griffith University's human research ethical clearance ICT/19/06/HREC.

\section{References}

Adya, M., \& Kaiser, K. M. (2006). Factors influencing girls' choice of information technology careers. In E. M. Trauth (Ed.), Encyclopedia of gender and information technology (Vol. 1, pp. 282-288). Hershey, PA: Idea Group Reference.

Beekhuyzen, J., \& Dorries, R. (2008). Tech girls are chic not just geeks. Retrieved from http://www.techgirlsarechic.org

Beekhuyzen, J., Nielsen, S. H., \& von Hellens, L. A. (2003). Challenging dualisms in female perceptions of IT work. Australian Journal of Information Systems, 10(2), 105-115.

Camp, T. (1997). The incredible shrinking pipeline. Communications of the ACM, 40(10), 103-110. 
Clayton, K. L. (2004). Information quality: The relationship to pre-tertiary IT education. Proceedings of the Informing Science and Information Technology Education Joint Conference, Rockhampton, Australia, 66-77, June 25-28. Available at http://proceedings.informingscience.org/InSITE2004/020clayt.pdf

Clayton, K. L. (2007). The influence of metropolitan Brisbane middle-school ICT experiences on girls' ICT study and career choices. PhD dissertation, Griffith University, December 2007.

Clayton, K. L., von Hellens, L.A., \& Nielsen S. H. (2009). Gender stereotypes prevail in ICT. A research review. Forthcoming in Proceedings of the ACM SIGMIS conference, Limerick, Ireland, 28-30 May 2009.

Cone, E. (2007). Why do women leave IT? ACM TechNews, CIO Insight, 82, p. 24. Retrieved 7 June, 2007, from http://www.cioinsight.com/article2/0,1397,2149170,00.asp

Craig, A. M. J. (2008). Attracting women to computing: A framework for evaluating intervention programmes. PhD dissertation, Monash University, June 2008.

Goldman, D. (2003). Reality bytes: A reflection of the perception versus the reality of teaching with ICT. IFIP Working Groups 3.1 and 3.3 Working conference: ICT and the Teacher of the Future, Melbourne Australia, January 2003.

Greenhill, A., von Hellens, L. A., Nielsen, S. H., \& Pringle, R. (1997). Australian women in IT education: Multiple meanings and multiculturalism. In Proceedings of the 6th International IFIP Conference on Women Work and Computerization (WWC 1997), Bonn, Germany, 387-397., 26-28 May.

Haffner, Y., Könekamp, B., \& Krais, B. (2006). Arbeitswelt in Bewegung. Chancengleichheit in technischen und naturwissesschaftlichen Berufen al Impuls für Unternehmen. (The world of work in motion, state of flux: Equal opportunity in technical and scientific professions as an impulse (driver) for businesses). Bundesministerium für Bildung und Forschung [Ministry for Education and research]. Accessed: 10 Oct 2007. Also published in Yvonne Haffner (2007) Mythen um männliche Karrieren und weibliche Leistung, Leverkusen Opladen: Barbara Budrich 2007. ISBN: 3-86649-050-X, http://www.bmbf.de/pub/arbeitswelt in bewegung.pdf (Accessed 28 Aug 2009)

Harris, R., \& Wilkinson, M. A. (2004). Situating gender: Students' perceptions of information work. Information Technology \& People, 17(1), 71-86.

Maxwell, J. A. (2005). Qualitative research design: An interactive approach ( $2^{\text {nd }}$ Ed). Thousand Oaks. Sage Publication.

Munder, I. (2005). Of mice and (wo)men. The diverse agendas of gender in teaching computer science in higher education. Proceedings of the 6th International Conference of Women into Computing, London, UK, pp. 299-316, 14-16 July.

Newmarch, E., Taylor-Steele, S. \& Cumpston, A. (2000). Women in IT - What are the barriers? Network of Women in Further Education Conference Showcase of Strategies for Women in Education on Information Technology Conference Paper.

Simard, C., Davies Henderson, A., Gilmartin, S. K., Schiebinger, L. \& Whitey, T. (2008). Climbing the technical ladder: Obstacles and solutions for mid-level women in technology. Anita Borg Institute for Women in Technology and Stanford University. Retrieved from http://www.anitaborg.org/news/research/

Trauth, E. M. (2002). Odd girl out: An individual differences perspective on women in the IT profession. Information Technology \& People, 15(2), 98-118.

von Hellens, L. \& Nielsen, S. (2001). Australian women in IT. Communications of the ACM, 4(7), 45-62.

von Hellens, L., Nielsen, S., Clayton, K. \& Beekhuyzen, J. (2007). Conceptualising gender and IT: Australians taking action in Germany. Proceedings of QualIT2007 - Qualitative Research in IT \& IT in Qualitative Research, Wellington, New Zealand, Victoria University of Wellington, 19-20 November. 
von Hellens, Clayton, Beekhuyzen, \& Nielsen

\section{Appendix A - Student survey}

University Letterhead

Hello :-

We are very interested in what you think about computers and doing computer work. We would like you to answer some questions about your opinions about computers. It will take about 30 minutes to do.

Please do not worry about what you think or write on this form. Nobody will be able to tell who filled out this form. These questions also have nothing to do with your school report or your grade.

Remember, you don't have to take part unless you want to. If you have any questions you should talk to your teacher. If they don't know the answer to your question, they can contact us for you.

Thank you for helping us with our work!

This research is being conducted by:

Names: Liisa von Hellens, Sue Nielsen, Kaylene Clayton and Jenine Beekhuyzen

School: School of Information and Communication Technology,

Griffith University, Australia

Contact Email: 1.vonhellens@griffith.edu.au

\section{WinIT Student Survey}
1. I am a : Boy
Girl $\square$
I don't want to say

2. Do you have access to a computer other than at school? (tick only one box)

Yes $\square \quad$ No $\square$

3.Do you use computers mostly at school or mostly at home? (tick only one box)

School $\square \quad$ Home $\square \quad$ About the same $\square$

4. How many hours do you use a computer per week? (tick only one box)

None $\square \quad 1-10$ hours $\square \quad 11-20$ hours $\square \quad 21+$ hours

5. What do you use computers for? (tick as many boxes as needed)

School work

Games

Web surfing
Email

Chatting $\square$

Music/movies

\section{Do you study a computer subject at school? Yes $\square \quad$ No $\square$}

7.What was the reason for your decision? (tick as many boxes as needed)

It is fun

It is boring

My parents told me to do it

My parents told me NOT to do it

I want to work in computing

There are more important subjects $\square$

I want to learn more about them
I do not like computers

It is interesting

My teachers/school told me to do it

My teachers/school told me NOT to do it

It fitted my schedule

I do not want a job using computers

I know everything about computers 
8.If you are studying or have studied a computing subject at school, how would you describe the subject (tick only one box)

Boring $\square \quad$ Sometimes interesting $\square \quad$ Very interesting $\square$

9.If you have studied a computer subject at school, was it what you thought it would be like? (tick only one box)

Yes $\square \quad$ No $\square$ I have not studied a computer subject

10. I enjoy solving problems and doing things with computers. Do you agree?

(tick only one box)

Yes $\square \quad$ No $\square$

11. I do not like to answer questions about computers in class because someone may make fun of me. Do you agree? (tick only one box)

Yes $\square \quad$ No $\square$

12. You have to be good at maths to be good with computers. Do you agree? (tick only one box)

Yes $\square \quad$ No $\square \quad$ I don't know $\square$

13. Boys are better with computers than girls are. Do you agree? (tick only one box)

Yes $\square \quad$ No $\square \quad$ I don't know

14. A person who works with computers is: (tick as many boxes as needed)

Smart

A problem solver

Creative

Hardworking

Team player

Rich

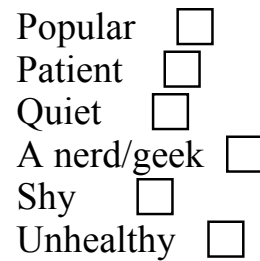

Popular $\square$

Patient

Quiet

Shy

Unhealthy

15. What sort of work do you think that a person with computer training does? (tick as many boxes as needed)

Sales

Data entry

Helping computer users

Choosing software/hardware for others to use

Programming

Clerical work

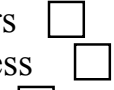

Writing/testing new software
Training Fixing computers/software $\square$

16. Has anyone encouraged you to study computing? (tick as many boxes as needed)

Mother

Brother/sister Father

Other family member

Friend

Teacher

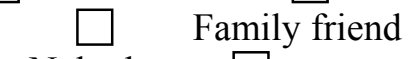

Nobody 
17. Has anyone discouraged you from studying computing? (tick as many boxes as needed)

Mother

Brother/sister

Father

Other family member

Friend $\quad \square \quad$ Nobody

Teacher

Family friend

18. Do you know what job or career you would like when finishing school?

Yes $\square$ (tick only one box)

19. Have you considered studying computers at a technical college or university? (tick only one box)

Yes $\square \quad$ No $\square$

20. The people/things that affect how I think about what I would like to do in the future for a job: (tick as many boxes as needed)

Mother

Father

Family

Movies

Books/magazines

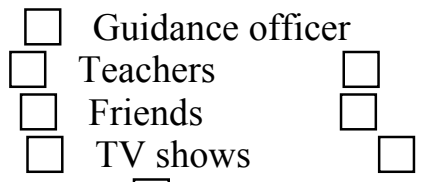

21. What things are important to you when choosing a career? (tick as many boxes as needed)

Working with other people $\square$ Good image/status

High salary/wage Interesting work

Challenging work

Self employment

Travel

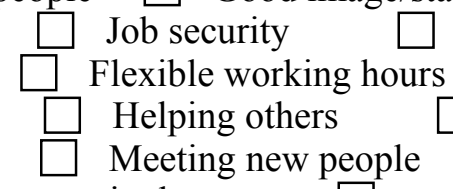

Interest in the area

22. Can you name ANY man working in or with computers who you see as a computing role model? (tick as many boxes as needed)

Father Brother

Other male in my family $\quad \square \quad$ Teacher

Friend

Neighbour

Family friend

Someone famous

Movie/TV character

Nobody

23. Can you name ANY woman working in or with computers who you see as a computing role model? (tick as many boxes as needed)

Mother

Other female in my family $\square \quad$ Teacher

Friend

Neighbour

Someone famous

Family friend

Movie/TV character

Nobody

Thank you for your time :) 


\section{Appendix B - Summary of Student Responses}

- Home is primary place of computer access - 97\% (155 students)

- Hours of computer use each week - 1-10 hours a week (43\%), 11-20 hrs/wk - 25\%, >21 $\mathrm{hrs} / \mathrm{wk}-32 \%$

- Study a computer subject at school? - yes $49 \%$, no $51 \%$

- Don't study a computer subject at school by choice $-26 \%$ (41 students)

- Why not study a computer subject at school - 'boring' - 34\%

- Why study a computer subject at school - want to learn more about them $-12 \%$

- Are computer subjects studied interesting - sometimes $46 \%$, very $10 \%$, boring $10 \%, 3 \%$ didn't say, $31 \%$ don't study a computer subject at school

- Is computer subject they study at school what they thought it would be like - yes $34 \%$, no $28 \%, 7 \%$ didn't answer, $31 \%$ don't study a computer subject at school

- Enjoy solving problems and doing things with a computer - yes $73 \%$, no $27 \%$

- Think someone will make fun of them if they answer computer questions in class - no $87 \%$, yes $13 \%$

- What a person with computer training does - programming 93\%, writing/testing new software (76\%), helping computer users $69 \%$, fixing computers/software $66 \%$, data entry $65 \%$, choosing software/hardware for others to use $63 \%$, managing a business $62 \%$, sales $30 \%$, supervising people $27 \%$, training $27 \%$, other $14 \%$, clerical work $14 \%$.

- Don't have to be good at maths to be good with computers - no $63 \%$, yes $16 \%$

- Are boys better with computers than girls - yes $43 \%$, no $44 \%$, others didn't answer or replied, "I don't know".

- Know what you want to do when you finish school - yes 51\%, no 48\%, 1 didn't answer

- Considered studying computers at technical college or university - yes $13 \%$

- Discouraged from studying computing - no $14 \%$

- Discouraged by who - mothers (10 students), friends (8), brother/sister (2), father (1), family member (1), family friend (1)

- Some were encouraged to study computing by more than one person

- Encouraged by who - father (24), mother (16), brother/sister (4), another family member (6), family friend (9), teachers (11), hostmother (1) 
von Hellens, Clayton, Beekhuyzen, \& Nielsen

\section{Biographies}

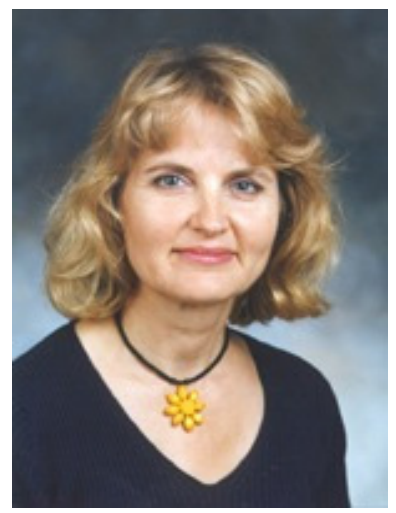

Liisa von Hellens is Associate Professor in Information Systems in the School of Information and Communication Technology at Griffith University. She is a published author on the subject of Enterprise Wide System Implementation and software quality management. Her doctoral dissertation investigated package software development and use; and her $\mathrm{PhD}$ degree is from Templeton College at Oxford University. She is Associate Editor of the Information Systems Journal and served at the Editorial Advisory Board for the Encyclopedia of Gender and Information Technology (Idea Group Reference). She was invited by Senator Helen Coonan while the Federal Minister for Communications, IT and the Arts to sit on the Advisory Committee for the 2005 Summit on Women in ICT. In 1995, Liisa von Hellens and Sue Nielsen established the Women in Information Technology Project (www.winitproject.com). In 2007 Liisa served as invited visiting Professor in Gender and IT in Hanover, Germany within the Maria Goeppert-Mayer programme.

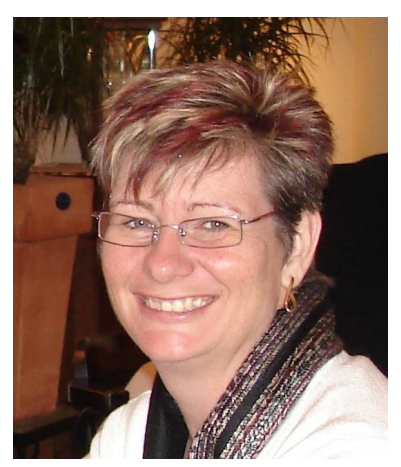

Kaylene Clayton's 2007 Ph.D. in the School of Information and Communication Technology at Griffith University investigated the influence of middle-school ICT experiences on girls' ICT study and career choices. As a product of this research, a model to assist researchers investigating under-representation of females in ICT has been created. She has previously completed an IT degree with honours, winning two medals for academic excellence. Her honours research project involved the exploration of ICT perceptions and experiences of Year 9 and 12 students and their teachers. In 2007, her achievements were recognized when she won the Queensland Government's ICT post-graduate student Smart Women - Smart State award. Over the past few years, she has been actively involved in a number of projects aimed at correcting the imbalance of females choosing to become involved in ICT by providing hands on activities, access to role models and mentoring.

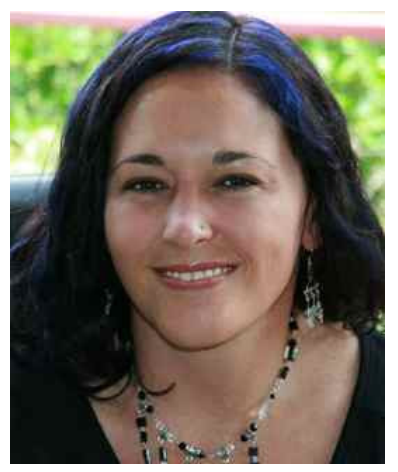

Jenine Beekhuyzen is a full time PhD student in the School of Information and Communication Technology at Griffith University, investigating technology and the online music experience. Jenine has been working in the WinIT Project (Women in IT) longitudinal study since 2000. Being an active researcher, she serves as a reviewer for a number information systems academic journals and conferences. She also puts this research into practice by working in the community. She has a keen interest in encouraging more girls into information technology and supporting the women that are currently in the industry and does this by being part of the organising group of the annual 'Technology Can Take You Anywhere' day ( 1500 girls), and she is also the editor of the book 'Tech girls are chic, not just geek'. She works at employing innovative methods (like mobile technology) to support these activities. 


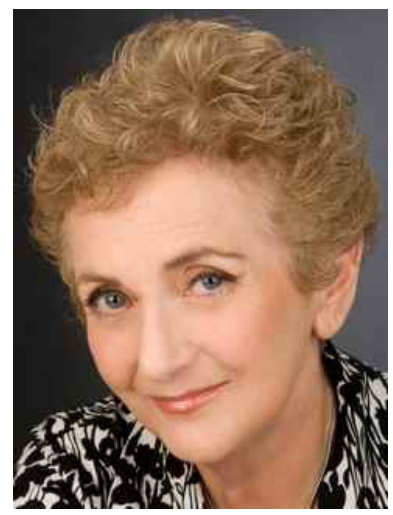

Sue Nielsen has taught and worked in Information Management and Information Systems for more than thirty years and is currently adjunct Senior Research Fellow in the School of Information and Communication Technology at Griffith University. As well as her involvement in the WinIT project (www.winitproject.com), she has carried out research on organisational culture and employee commitment in information systems development and software quality management. Her $\mathrm{PhD}$ from Griffith University used ethnographic methods and discourse analysis to study change management in an information technology centre. Her other major interests are Auslan (Australian sign language) and science fiction; her new novel "Behind the Sun" is now available from Amazon.com 